\title{
BESZÁMOLÓ A NÓGRÁD MEGYEI PEDAGÓGIAI KONFERENCIÁRÓL
}

(Balassagyarmat, 2016. május 18.)

Szerzők:

Dupákné Gecse Adél

Salgótarjáni Pedagógiai Oktatási Központ

Vágvölgyiné Bene Orsolya

Salgótarjáni Pedagógiai Oktatási Központ

Első szerző e-mail címe:

dupakne.gecse.adel@oh.gov.hu
Lektorálta és jóváhagyta:

Selmeczi Zoltán

főosztályvezető

Oktatási Hivatal

Salgótarjáni Pedagógiai Oktatási Központ

Dupákné Gecse A. és Vágvölgyiné Bene O. (2016): Beszámoló a Nógrád Megyei Pedagógiai Konferenciáról. Balassagyarmat, 2016. május 18. Különleges Bánásmód, II. évf. 2016/1. szám, 105-109. DOI 10.18458/KB.2016.1.105

Az Oktatási Hivatal Salgótarjáni Pedagógiai Oktatási Központja (Salgótarjáni POK) 2016. május 18-án tartotta Nógrád Megyei Pedagógiai Napjának plenáris konferenciáját. A rendezvénynek a balassagyarmati Mikszáth Kálmán Müvelődési Központ adott helyet. A konferencia célja egyrészt az volt, hogy tájékoztatást nyújtson a megyei köznevelési intézmények vezetőinek és pedagógusainak a közelmúlt köznevelést érintő változásairól, másrészt a szakmai előadások révén kitekintést adjon a különböző pedagógiai témákra.

A felvonultatott témák sokrétüségét bizonyítja a meghívott előadók széles skálája. Brassói Sándor, az Oktatási Hivatal köznevelési elnökhelyettese és Thaisz Miklós, az EMMI főosztályvezetője mellett a tehetséggondozás jegyében szót kapott Dr. Mező Ferenc egyetemi docens, az iskolai egészségnevelés témában dr. Somhegyi Annamária, míg a mérés-értékelés területén Ostorics László, az Oktatási Hivatal megbízott osztályvezetője.

A konferenciát Selmeczi Zoltán, az Salgótarjáni POK főosztályvezetője Szent-Györgyi Albert idézetével nyitotta meg: „Olyan lesz a jövőnk, mint amilyen a ma iskolája!”. Köszöntőjében kitért arra, hogy a Salgótarjáni POK a jövőben szakmai konferenciáit igyekszik a megye több városába is elvinni, mert csak így ismerhetjük meg egymás életét és munkakörülményeit, ami a szoros együttmüködés egyik feltétele (1. kép).

A konferencia első előadója Brassói Sándor az Oktatási Hivatal köznevelési elnökhelyettese volt, aki az Oktatási Hivatalnak a köznevelési ágazat szakmai támogatásában történő feladatbővüléséröl beszélt. Így - többek között - az országosan 15 POK létrejöttének szükségességéről, azok feladataikról, a pedagógus továbbképzések megújulásának szükségességéről, a tematikus szaktanácsadásra vonatkozó megnövekedett intézményi igényekről és azok kielégítésének problémáiról, az országos tanulmányi versenyek körének kibővüléséről, valamint a 2016-os évre várható fejlesztési irányokról. 
1. kép: Nógrád Megyei Pedagógiai Konferencia (Balassagyarmat, 2016. május 18.)

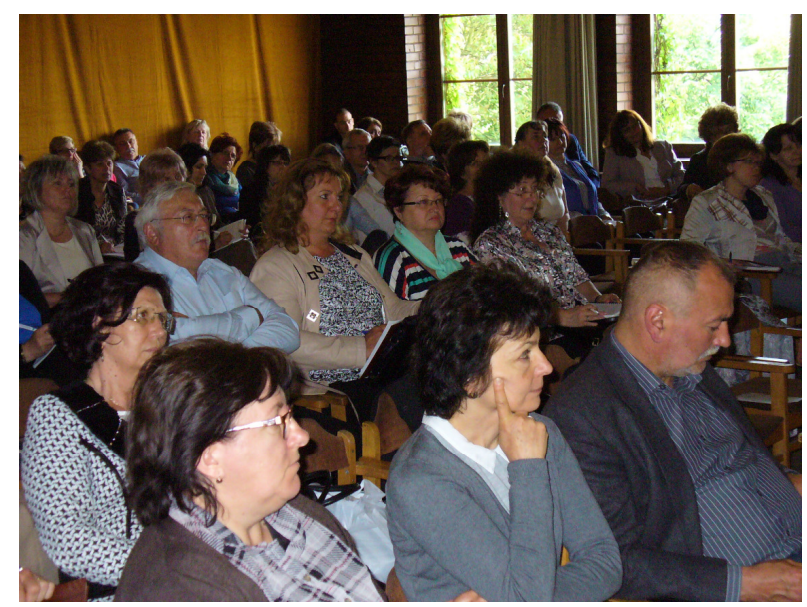

2. kép: Brassói Sándor köznevelési elnökhelyettes

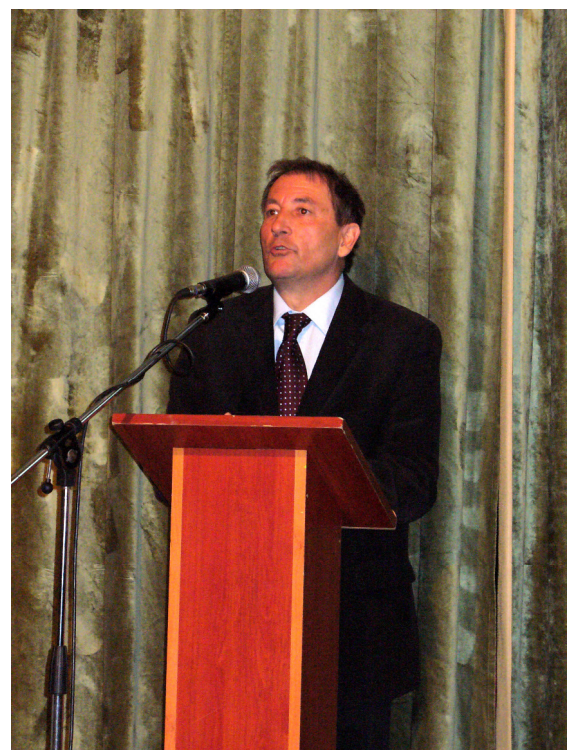

Az előadók közül másodikként Thaisz Miklós, az EMMI Köznevelésért Felelős Helyettes Államtitkárság Köznevelési Stratégiai Föosztályának vezetője kapott szót. Előadása első részében az elmúlt hónapok társadalmi egyeztetéseinek eredményeiröl tájékoztatta a jelenlévőket, többek között a Köznevelési Kerekasztalról, a döntésekre gyakorolt szerepéről, a munkacsoportok jelentőségéről, az azokban szerepet vállaló szervezetekről és személyekről. Az elöadás második részében a 2017. évi minősítésre és tanfelügyeletre vonatkozó információk hangzottak el. A minősítési eljárások lefolytatása országosan rendben zajlik, míg az eddig lebonyolított tanfelügyeleti látogatások tapasztalatai alapján ezen a téren változások, könnyítések várhatók. A minősítési és tanfelügyeleti rendszer esetleges hiányosságait a 
szervezők igyekeznek folyamatosan korrigálni, ezzel is elősegítve a pedagógus minősítési rendszer társadalmi elfogadottságát. Az előadás végeztével a szervezők lehetőséget biztosítottak a résztvevőknek az esetlegesen megfogalmazódott kérdéseik feltételére is. (3. kép)

3. kép: Thaisz Miklós föosztályvezetö a kérdések megválaszolása közben

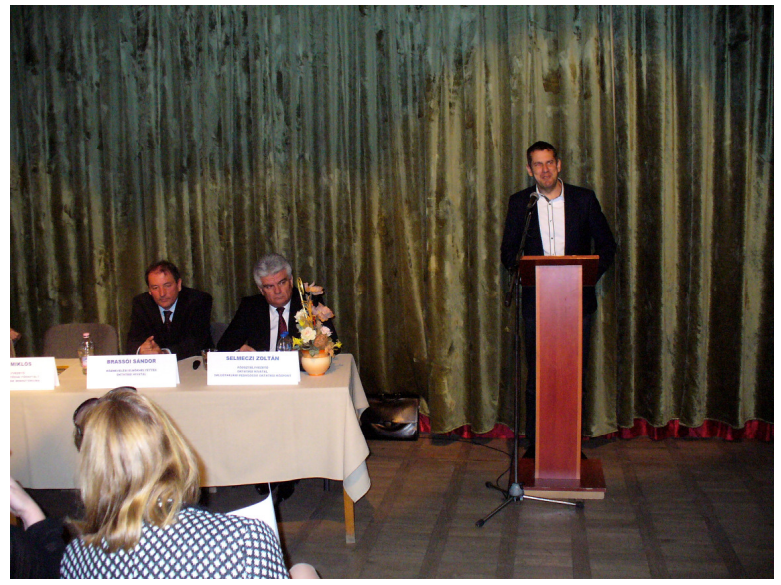

A délelőtt harmadik programjaként Dr. Mezö Ferenc, a Debreceni Egyetem docense szólította meg szuggesztív módon a jelenlévőket. Előadása A tehetségdiagnosztika és tehetséggondozás a gyakorlatban téma köré épült. Prezentációja során elsősorban a tehetséggondozás alapfogalmait elevenítette fel, miközben számos olyan helyzetre, összefüggésre hívta fel a pedagógusok figyelmét, amelyek nem hagyhatók figyelmen kívül a tehetségdiagnosztika, a beválogatás és a tehetséggondozó program tervezése és megvalósítása során (például a „sors”faktor szerepe, a tehetséggondozás egyéni, intézményi, települési, megyei szintjeinek megvalósíthatósága, stb). Előadását nagy érdeklődés kísérte, hiszen a tehetséggondozás a köznevelés egyik stratégiai kérdése. A közös munka folytatása érdekében elvi együttmüködési megállapodás született a tehetséggondozással kapcsolatos pedagógus-továbbképzések megvalósítása érdekében, így feltehetően hamarosan ismét találkozunk Mező Ferenccel Nógrád megyében (4. kép).

\section{4. kép: Dr. Mezö Ferenc oktató, kutató}

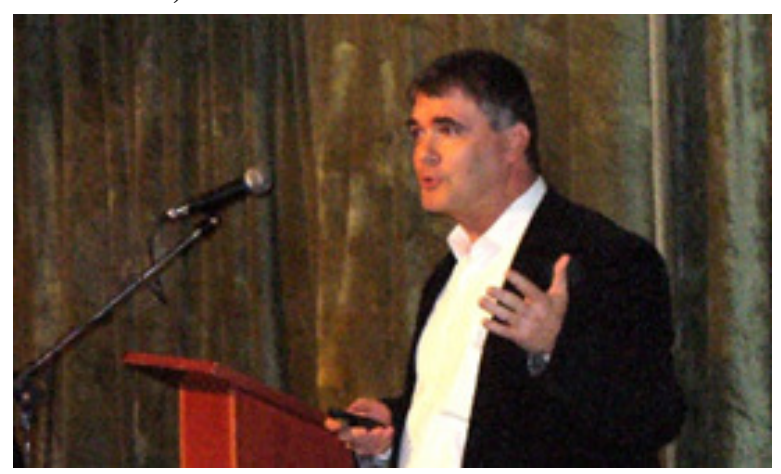


A szakmai nap délutánja „A Teljeskörü Iskolai Egészségnevelés (TIE) mindennapi teendői az iskolában" címmel Dr. Somhegyi Annamária PhD., az Országos Gerincgyógyászati Központ prevenciós igazgatójának előadásával folytatódott. Előadásának központi gondolata volt annak megerősítése, hogy a gyermekeink egészségének védelme érdekében szükséges a népegészségügyi célok közpolitikába helyezése. Eredményesnek minősítette, hogy Magyarországon ez sikerült, azaz a köznevelés és egészségügy együttmüködése látható, érzékelhető a jogszabályokban is, valamint az e célokat szolgáló projektek eredményeiben is:

- (TÁMOP 3.1.13. (Magyar Dietetikusok Szövetsége): testnevelök megfelelő szemléletének kialakítása (8000 testnevelő továbbképzése, 7 szakmai kiadvány, Netfit)

- TÁMOP 6.1.1. (Nemzeti Egészségfejlesztési Intézet): 11 elméleti anyag, 7 irányelv, 6 modellprogram, munkaértekezletek

- TÁMOP 6.1.2. (Nemzeti Egészségfejlesztési Intézet és Klebelsberg Intézményfenntartó Központ): 10 EPSZA-füzet, 2 módszertani anyag, TIE koncepció döntéshozóknak, iskolai egészségkultúra kutatás

Az egészségnevelés területeit, feladatit, megvalósítási lehetőségeit széleskörü kitekintéssel, gazdag ötlettárral és további web oldalak javasolásával, a pedagógusok számára letölthetö kiadványok ajánlásával tette valóban gyakorlatiassá (5. kép).

\section{5. kép: Dr. Somhegyi Annamária elöadása közben}

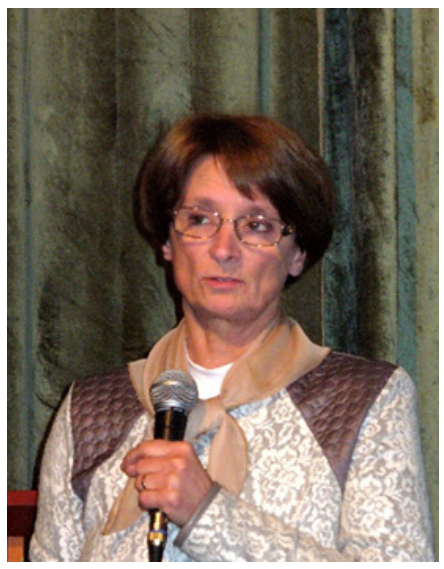

Iskolalisták a kompetenciamérés adatainak tükrében címmel Ostorics László, az Oktatási Hivatal Köznevelési Mérés Értékelési Osztály megbízott osztályvezetője zárta a szakmai programok sorozatát. Előadásának főbb kérdései voltak:

- Mit tekint „legjobb 100” iskolának a közgondolkodás? (Mit jelentenek az abszolút eredmények: „nyers erősorrend”? Levonható-e ebből bármiféle következtetés?)

- Mi az országos kompetenciamérés tágabb értelmezése a ,jó iskoláról”? (Kontextusban vizsgált eredmények: társadalmi összetétel és az előzetes teljesítmény összefüggései)

- Kik a jók a kontextusban vizsgált eredmények alapján? (A legerősebb hátránykompenzáló iskolák müveltségi terület, évfolyam és iskolatípus szerint, valamint a legerősebb fejlesztő iskolák müveltségi terület, évfolyam és iskolatípus szerint)

A szakmai fül számára nagyon is előremutató és pedagógiai szempontból is megnyugtató volt hallatni azt, hogy a szakmai irányítás fontosnak tartja az ,adatok mögé tekintést”, a teljesítményt prognosztizáló és meghatározó tényezők számbavételét egy-egy lista (rangsor?) elkészítésekor. Különösen izgalmas volt az elöadás gondolatmenetének végkifejlete: vannak 
iskolák, amelyek a különböző kontextusban vizsgált eredmények alapján is ,,jók”, azaz ök lehetnek azok az intézmények, akiktől lehet tanulni, mert valamit nagyon jól csinálnak.

A szakmai rendezvényt Selmeczi Zoltán föosztályvezető zárta, megerősítette a közös gondolkodás fontosságát és folyamatosságának szükségességét. 